\title{
Out of sight but no longer out of mind: a climate of change for marine conservation in Madagascar
}

\author{
Alasdair R. Harris
}

\begin{abstract}
With over $5,500 \mathrm{~km}$ of coastline spanning more than 14 degrees of latitude, Madagascar boasts a diversity of marine and coastal habitats that is unrivalled in the Indian Ocean. These ecosystems are of paramount importance to national food security, as well as the livelihoods and culture of coastal people. Yet Madagascar's fragile marine resources are facing unprecedented threats from climate change, habitat destruction and overfishing. Development of an ecologically robust national marine protected area network presents the only viable means of safeguarding the resilience of remaining healthy ecosystems. But in the current post-crisis context, characterised by a lack of fully functional national environmental governance institutions, severe funding gaps and pervasive coastal poverty, conventional centralised approaches to marine protected area planning and management are unable to respond effectively to the scale and immediacy of the challenge. Given these constraints, the ongoing expansion of local coastal governance efforts will be key to promoting socially viable adaptive management strategies. Encouragingly, the recent rapid growth and scaling-up of locally managed marine areas (LMMAS) in Madagascar is unsurpassed throughout east Africa and the Indian Ocean region, with communities pioneering new and innovative approaches to fisheries management and livelihood diversification. The durability of such local conservation efforts, however, will depend on their capacity to demonstrate the economic as well as biodiversity benefits of sustainable marine resource management. This challenge necessitates placing a renewed focus on proving, quantifying and communicating the utilitarian benefits of marine biodiversity. Making this business case will be a fundamental prerequisite to stemming the tide of marine environmental degradation in Madagascar, and tackling the twin tragedies of coastal poverty and the marine commons.
\end{abstract}

\section{RÉSUMÉ}

Bordés par plus de $5500 \mathrm{~km}$ de côtes qui s'étirent sur plus de 14 degrés de latitude, Madagascar peut s'enorgueillir de posséder la plus belle et la plus riche diversité des habitats marins et côtiers dans I'océan Indien. Ces écosystèmes sont d'une importance capitale pour la sécurité alimentaire du pays mais aussi pour le bien-être et les valeurs culturelles des communautés locales côtières. Les ressources marines de Madagascar sont pourtant fragiles et confrontées à des menaces sans précédent

\author{
Blue Ventures Conservation \\ Aberdeen House, 22-24 Highbury Grove \\ London, N5 2EA, U.K. \\ E-mail: al@blueventures.org
}

dont les effets du changement climatique, la destruction des habitats et la surpêche. Le développement d'un réseau national d'aires marines protégées, fondé sur des valeurs écologiques sera le seul moyen viable pour sauvegarder la résilience des écosystèmes naturels restants. Dans le contexte de crise politique actuel caractérisé par l'absence d'institutions nationales fonctionnelles en matière de gouvernance environnementale, le manque de financement adéquat sans oublier la paupérisation galopante des communautés des régions côtières, il est difficile de suivre les méthodologies traditionnelles et centralisées pour la planification des aires marines protégées car elles ne sont pas en mesure de répondre efficacement à l'étendue de la tâche à accomplir et à l'urgence de la situation.

Face à ces contraintes et dans le dessein de promouvoir des stratégies de gestion adaptative et socialement viables, il s'agira d'étendre davantage les efforts de gouvernance locale portant sur les zones côtières. II est encourageant de noter que les aires marines gérées localement (LMMAs) se développent rapidement et à un taux qui est inégalé en ce qui concerne I'Afrique de l'Est ou la région de l'océan Indien. Dans ce système de gestion, les communautés locales adoptent des approches novatrices dans la gestion de la pêche ainsi que dans la diversification de leurs moyens de subsistance. La durabilité de tels efforts de conservation au niveau local dépendra cependant de la capacité de ces communautés à reconnaître les avantages de la gestion pérenne des ressources marines, en terme économique et en matière de biodiversité. Relever ce défi suppose que de réels progrès soient accomplis dans la démonstration, la quantification et la communication des avantages à protéger la biodiversité marine. Aborder la question en soulignant la rentabilisation est une condition sine qua non pour endiguer la spirale de la dégradation de l'environnement marin à Madagascar.

Pour envisager le futur, les protecteurs de la nature doivent regarder au-delà de la protection de la biodiversité marine pour la seule valeur intrinsèque des récifs coralliens. Ils devront s'appliquer à démontrer la valeur des écosystèmes marins et côtiers lorsqu'ils sont sains en tant que composantes d'un avenir durable pour les communautés locales qui respectent et préservent ces ressources. Si la grande Zone Économique Exclusive de Madagascar, incluant les diverses pêcheries côtières et marines, était correctement gérée, elle serait une source garantie et permanente pour la sécurité alimentaire et une source de devises. Le défi à relever par les protec- 


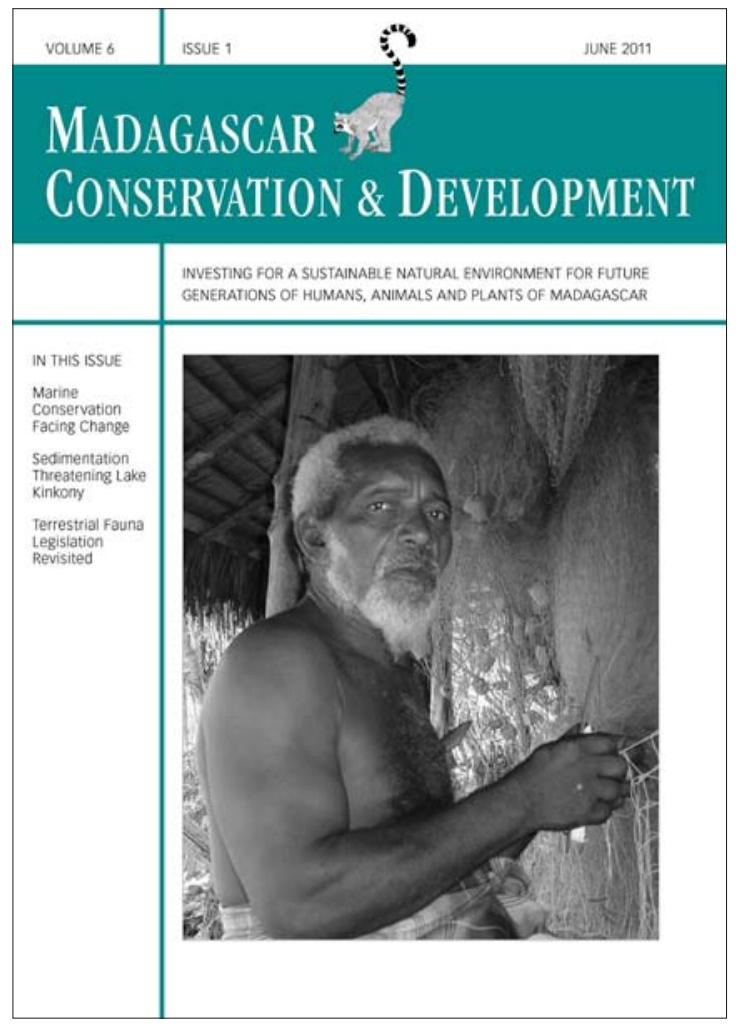

Madagascar Conservation \& Development is the journal of Indian Ocean e-Ink. It is produced under the responsibility of this institution. The views expressed in contributions to MCD are solely those of the authors and not those of the journal editors or the publisher.

All the Issues and articles are freely available at http://www.journalmcd.com

Contact Journal MCD

info@journalmcd.net for general inquiries regarding MCD funding@journalmcd.net to support the journal

Madagascar Conservation \& Development Institute and Museum of Anthropology University of Zurich

Winterthurerstrasse 190

CH-8057 Zurich, Switzerland

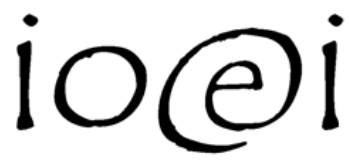

Indian Ocean e-Ink

Promoting African Publishing and Education www.ioeink.com

Missouri Botanical Garden (MBG)

Madagascar Research and Conservation Program BP 3391

Antananarivo, 101, Madagascar 
teurs des ressources océaniques sera de le prouver dans un contexte économique en démontrant que la biodiversité marine gérée de manière pertinente pèse bien davantage lorsque sont considérés les services incalculables et illimités qu'elle rend dans des écosystèmes sains. II nous appartient de le faire admettre mais nous n'ignorons pas que cette tâche sera une véritable course contre la montre.

KEYWORDS: Madagascar, marine conservation, coral reef, fisheries, PES.

MOTS CLEFS : Madagascar, protection des milieux marins, récif corallien, pêcheries, paiement pour les services d'écosystème.

\section{CONTEXT}

With its place firmly secured amongst the hottest of the global biodiversity hotspots, Madagascar is renowned not only for its exceptional concentration of species - many of which occur nowhere else on earth - but also because these outstanding biological riches are gravely threatened by man (Brooks et al. 2006). For over 20 years this global conservation prioritisation has played a crucial role in steering conservation finance and resources towards Madagascar. The original notion of a biodiversity hotspot, however, is rooted in an exclusively terrestrial concept, dealing only with issues facing species on land (Myers 1988, 2003). And paradoxically, the focus given to Madagascar's hotspot status has at times meant that environmental challenges below the waves have been eclipsed by the many threats facing the island's terrestrial biodiversity.

This is true the world over, where marine conservation has historically been slow off the mark relative to efforts to address terrestrial environmental concerns. But in Madagascar, creating momentum in marine conservation has been a particular challenge, not only because of the daunting scale of the island continent's coastline and weak infrastructure, but also because its marine biodiversity does not share the levels of endemism that are seen on land. Madagascar's seas are certainly extremely diverse - for example boasting more coral species than any other country in Africa, the Indian Ocean or Red Sea (Veron and Turak 2005). Yet what little is known of the country's marine fauna and flora indicates its marine biodiversity is broadly characteristic of Madagascar's position in the southwestern Indian Ocean, with many species in common with coastal east Africa and western Indian Ocean island and atoll systems. This situation is to be expected, since the deep ocean basins surrounding Madagascar do not present a barrier to the dispersal of marine species as they do for terrestrial plants and animals. At a global scale, in terms of overall marine diversity, species richness across the Indo-Pacific declines markedly with approximately increasing latitude away from the southeast Asian marine biodiversity centre, the 'Coral Triangle' (Veron et al. 2009). Thus Madagascar has so far not featured amongst the various rankings of the world's centres of tropical marine endemism that have been developed, following the original terrestrial hotspot framework (Roberts et al. 2002).

Despite its low levels of marine diversity and endemism relative to the central Indo-Pacific, Madagascar's marine natural heritage stands apart for two key reasons. Firstly, it is distinct from its Indian Ocean neighbours in its bewildering array of habitats. The island harbours a marine environmental diversity that rivals Madagascar's range of terrestrial bioclimatic zones.
This is perhaps unsurprising in a country with the largest coastline of any nation in the Indian Ocean except India; exceeding the lengths of the coastlines of Comoros, Mozambique, Tanzania and Kenya combined. Spanning over 14 degrees of latitude from temperate oceanic environments in the south to tropical lagoonal ecosystems in the west and north, no other country in the region exhibits such a rich diversity of marine ecosystems. Madagascar is endowed with the full array of tropical and subtropical marine and coastal habitats on a range of underlying strata. From high-energy rocky shores to steep oceanic beaches, the island's east coast faces the brunt of strong prevailing trade winds and the South Equatorial Current. Conversely the leeward side of the island exhibits some of the Indian Ocean's most extensive mangrove forests, seagrass beds and coral reefs. Myriad islands and archipelagos also emerge from the broad continental shelf around the west coast, including basaltic seastacks, coral platforms, cays and atolls.

Secondly, Madagascar's marine environment is a critically important source of food security and revenue for the country's population, over half of which lives within $100 \mathrm{~km}$ of the coast (WRI 2003). Many coastal communities have such close cultural ties to a seafaring way of life that they have no viable subsistence or economic alternatives to fishing. Coastal zones include some of Madagascar's most isolated and economically marginalised populations, who often have no alternative to over-exploitation of fisheries resources as the sole source of income and the only perceived path out of poverty. But in resource-dependent communities this coping mechanism serves to deepen the poverty trap, further degrading the natural capital upon which fisheries depend, and driving fishers to adopt increasingly destructive practices to maintain landings, in turn further weakening the resilience of ecosystems and biodiversity underpinning food and livelihoods (Cinner et al. 2009a, 2011). Recent research has shown that diminishing fisheries returns are a key factor driving Madagascar's semi-nomadic vezo communities further afield through migration, with shark fishers increasingly exploiting ever more remote and off-shore areas of the west coast of Madagascar (Cripps 2009, 2010).

It is a grim Malthusian cycle that is currently being played out by unprecedented numbers of fishers along all but the most inaccessible of Madagascar's western coasts, and exacerbated by the rapid rates of human population growth typical of many coastal regions. Characteristic of many countries in the western Indian Ocean, expansion of Madagascar's coastal populations is taking place more rapidly than across the island as a whole; in the southwestern Atsimo Andrefana region women give birth to an average of 6.2 children. Across this region, home to approximately half of Madagascar's traditional fishers (Laroche and Ramananarivo 1995, Laroche et al. 1997), the population grew by $53 \%$ in the 15 years leading up to 2008, and is forecast to grow by the same amount in the next 13 years (INSTAT 2007, INSTAT and ICF Macro 2010).

Moving offshore, in recent years growing concerns have been voiced amongst local fishers and industry groups alike regarding the growth of Madagascar's commercial fishing effort (Le Manach et al. In press a). Based on 2001 data, Madagascar's fishing industry (including aquaculture) contributed more than $20 \%$ to total export earnings, representing $8 \%$ of gross domestic product (FAO 2008). Despite their importance, current understanding of the trends and sustainability of Malagasy fish- 
eries remains poor, and almost nothing is known of the scale of illegal, unreported and unregulated fishing in Madagascar's exclusive economic zone (EEZ). Effective industrial fisheries management requires rigorous monitoring, effective enforcement, science-based quotas, adaptive management, and a network of managed offshore zones, none of which currently exist in Madagascar. A recent reconstruction of total catches by all Malagasy fisheries sectors has shown that total catches between 1950 and 2008 were twice the volume reported by national fisheries agencies, with much of the subsistence sector missing from officially reported statistics. These findings clearly suggest that current landings are likely to be exceeding sustainable yields (Le Manach et al. In press a, b). And from onshore, often many hundreds of kilometres upstream, watershed degradation continues to present a particular problem, due to ongoing deforestation and burning that have lead to massive erosion. The resulting fluvial sediment loads can lead to abrasion and asphyxiation of fragile benthic habitats, a particular problem where the country's largest rivers meet the broad western lagoons and coral reefs (Vasseur 1997).

From unsustainable fishing and population growth to hypersedimentation of reefs from terrigenous sediments, Madagascar's marine natural heritage is under siege from human activities on land and sea. And beyond direct anthropogenic impacts, the unrelenting effects of a changing global climate are challenging more than ever the work of conservationists seeking to stem the loss of the island's marine biodiversity. Climate impacts range from coral reef bleaching and mortality to coastal erosion and increased cyclonic activity. Madagascar is ranked amongst tropical coastal countries with the lowest adaptive capacity to climate change, combined with very high vulnerability (Burke et al. 2011, Cinner et al. 2009b); a recent forecast of the threats of climate change across the western Indian Ocean indicates that in Madagascar the impacts of ocean acidification and thermal stress will coincide, resulting in particularly dramatic changes by 2030 (Ateweberhan and McClanahan 2010).

These trends and predictions not only have profound implications for biodiversity conservation, but also for food security in a country where people rely heavily on the ocean for their daily protein needs, livelihoods and traditional coastal cultures. Many coastal habitats have already been degraded to the point where recovery is now unlikely (Ahamada et al. 2008, Harris et al. 2010) therefore there is now more than ever an overwhelming imperative for protection of remaining healthy habitat. This will be fundamental to safeguarding resilience to future climatic disturbance, as well as creating an ecologically-robust network of refugia to help reseed the recovery of more degraded areas.

\section{THIRTY PERCENT: A FORMIDABLE TARGET IN A TIME OF CRISIS}

Throughout its short history to date, marine and coastal conservation in Madagascar has been broadly synonymous with area-based management of coral reefs, achieved mainly through the development of marine protected areas (MPAs), within which access to - and use of - marine resources is controlled, usually through gear or access restrictions to fishers. Typically these MPAs have been developed by conservation NGOs and Madagascar's parks service (Madagascar National Parks), to whom management authority has been invested by the state, either as a single organisation acting alone, or in conjunction with local communities through a co-management framework.

This focus on coral reefs as concentrations of marine biodiversity has left many other vital marine ecosystems overlooked in conservation planning. Habitats such as seagrass beds, coastal lagoons and mangrove forests do not rival the sheer biodiversity of coral reefs, but are of enormous ecological importance nonetheless, providing essential habitat for numerous fish and invertebrate species, and supporting some of the country's most productive fisheries. For example Madagascar boasts the third largest area coverage of mangroves of any coastal African nation. These coastal forests boast exceptionally high rates of net primary productivity (Ostling et al. 2009), protect thousands of kilometres of Madagascar's coastline from the destructive forces of storms and cyclones, trap terrigenous sediments, and provide refugia, nursery grounds and feeding areas for diverse reef and pelagic species. Globally, they are estimated to support an annual market value of capture fisheries of around \$US 16,750 per hectare. Yet these forests, which have been reduced by at least $7 \%$ in the last three decades (Giri and Muhlhausen 2008), have until recently remained conspicuously absent from marine conservation planning.

The previous government's 2003 Durban Vision placed a particular emphasis on the expansion of marine protected area coverage. This, combined with growing civil society interest and awareness of marine issues, has resulted in a huge geographic expansion of marine management activity over the last eight years, with a rapid proliferation of site-based conservation activities. From three gazetted marine protected areas in 2002 to over 15 under temporary or permanent protection in 2010 (REBIOMA 2011), the combined spatial coverage of Madagascar's marine protected areas has grown over 50 -fold in the last nine years, most recently following interministerial decree 52005 in December 2010, which accorded provisional protected status to seven new MPAs (Figure 1). The effectiveness of management within this new generation of MPAs remains to be tested, and is likely to be highly variable, depending on size, ecosystem health, threats and the local acceptability of conservation efforts. Nonetheless, it is encouraging that these new protected areas also incorporate additional habitats beyond shallow coral reefs, safeguarding other critical marine ecosystems, notably mangroves and lagoonal habitats. Although now technically defunct within the abandoned Madagascar Action Plan (GoM 2007), the Durban Vision's momentum around marine protected area expansion continues to make waves.

Notwithstanding the benefits and ecosystem services flowing from Madagascar's rapidly expanding network of MPAs, these initiatives remain highly localized: essentially islands of protection within an otherwise worrisome ocean of unabated marine resource degradation. Despite the progress in the 2010 decree, still only $2 \%$ of the country's $3,934 \mathrm{~km}^{2}$ of coral reef are protected within the existing system of gazetted MPAs (Burke et al. 2011), no MPA currently protects offshore or deepwater pelagic habitats, and none of Madagascar's fisheries are currently recognised as sustainable.

MPA theory and empirical evidence indicate that 20-30\% protection is the realistic threshold required to maintain ecological resilience and ensure the long-term protection of marine ecosystems and ecological processes, with representa- 


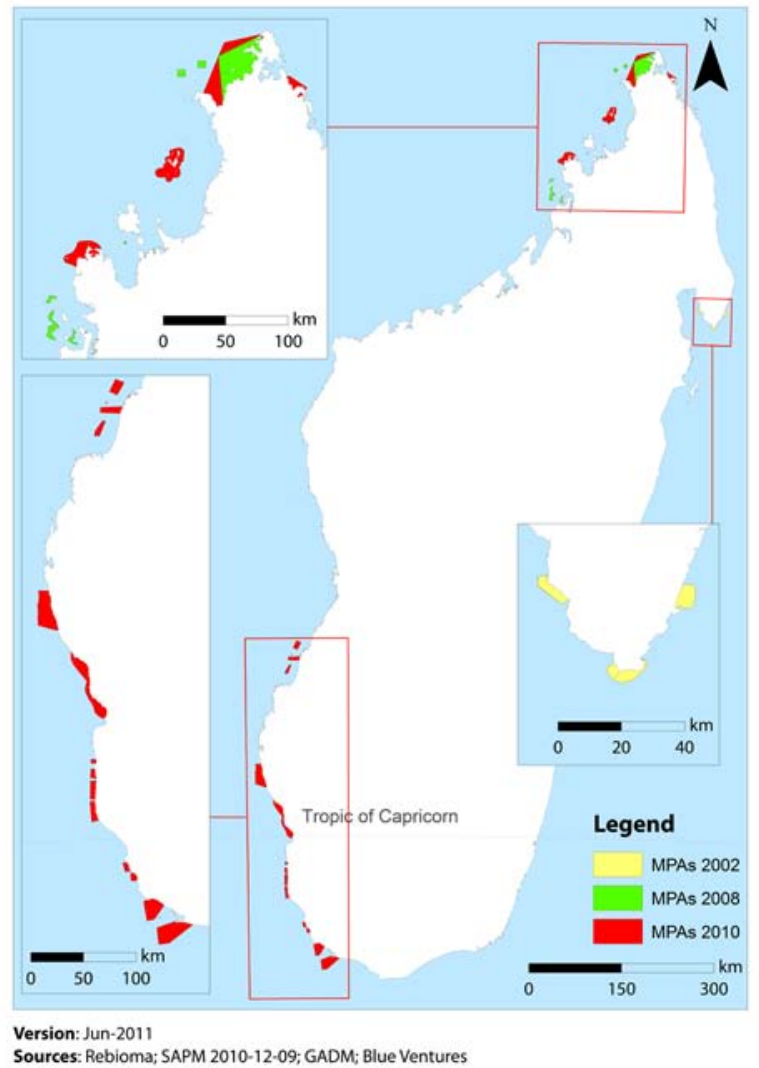

FIGURE 1. Marine protected areas with permanent or temporary protected status, 2002-2010.

tive inclusion of all habitats and patterns of connectivity, from mangroves to pelagic environments (Gell and Roberts 2002, Balmford et al. 2004, IUCN 2005 Recommendation V.22). Clearly, although isolated MPAs are useful for the protection of biodiversity and fisheries at a local scale, as well as providing case studies for inspiring other coastal management efforts, Madagascar's current system of marine protection remains woefully inadequate. Broader networks of connected protected areas will be essential to safeguard marine ecosystems from the forecast impacts of climate change at an ecologically robust scale. Even with the recent mushrooming of Malagasy MPA coverage, prioritisation still focuses disproportionately on coral reefs, and the extent to which many existing sites are respected or even known of by local communities remains doubtful.

Within the context of Madagascar's ongoing political crisis, characterised by an absence of fully functional government institutions and severe funding gaps, maintaining a strategic vision for MPA expansion will face far-reaching challenges. Official aid to Madagascar (traditionally accounting for almost half of the government's budget) has been cut dramatically since the 2009 military-backed coup, with environmental aid flows tumbling from US\$50.1 million in 2008 to just US\$16.2 million in 2010 (World Bank 2011). Given Madagascar's broader economic challenges, national-level support and finance for marine conservation are unlikely to be sufficient to achieve these formidable objectives.

\section{LOOKING LOCAL}

One strategy that has recently proven effective in expanding Madagascar's coastal management efforts without drawing on national resources is the development of Locally Managed
Marine Areas (LMMAs). These focus on empowering local communities with the responsibility for coastal management, ensuring close alignment with local populations' interests. Unlike many areas of the Pacific, where customary management of coral reefs has been practiced by communities for centuries (Johannes 1978), Madagascar, like its neighbours in the western Indian Ocean, has no tradition of marine tenure or community-based coastal resource governance for conservation, and its first LMMAs have been created only in recent years (Cinner 2007). In recent years, however, concerted efforts by NGOs to promote community-based coastal conservation have coincided with national policies to promote decentralised natural resource management, in particular through co- and community-managed protected areas.

Located in southwest Madagascar, Velondriake (meaning "to live with the sea") is Madagascar's first LMMA (Harris 2007), and at more than $1,000 \mathrm{~km}^{2}$ is the Indian Ocean's largest to date. Home to over 6,650 people in Atsimo Andrefana region, velondriake unites 24 coastal villages in the collaborative local management of a complex coastal ecosystem comprising islands, mangrove embayments, extensive lagoons and coral reefs. Average daily per capita income in Velondriake is under \$US 1.4 (adjusted for purchasing power parity), with $85 \%$ of incomes derived from fishing or reef gleaning. Given this backdrop of severe economic deprivation and fisheries dependence, Velondriake's over-riding objective is poverty alleviation through enhancing the sustainability of the region's fisheries. The LMMA contains temporary and permanent reserves protecting reefs and mangrove forests, and is managed through a dina - traditional village laws governing resource use that have been legalised by the state. Importantly, the dina also bans destructive fishing practices - primarily poison fishing and beach seining - widely seen by local communities as the primary drivers of marine resource degradation (Andriamalala and Gardner 2010). Malagasy law gives strong enforcement and conflict resolution powers to the local communities, allowing them to impose fines for infractions of the dina, and being locally led, Velondriake's laws enjoy high compliance.

At a local level, communities lack the know-how and means to independently establish LMMAs. Encouraging replication of this management approach beyond the local level therefore necessitates sharing experiences of best practice through community exchanges and dialogue. To this end, Velondriake is being used as a demonstration and learning site for other fishing communities of what can be achieved through local coastal management. Following these exchanges, in recent years new village-based initiatives have been established along Madagascar's southern, western and northern coasts with the support of numerous communities and NGOs working to replicate Velondriake's experiences. In southern Madagascar alone, seasonal no take zones for octopus Octopus cyanea - a management approach pioneered in Velondriake in 2004 to safeguard the region's most economically important fishery - have been replicated over 100 times along over 350 kilometres of coastline in just seven years. This scaling up through dialogue, achieved at low cost without drawing on national resources, is making considerable headway towards creating a new network of community based coastal conservation areas that will help promote greater ecological resilience to future environmental change. 
Alongside the benefits brought to fisheries management and biodiversity conservation, empowering communities for local environmental governance strengthens human social capital by promoting responsible environmental stewardship and building community cohesion. This creates numerous positive social and ecological synergies that both enhance the effectiveness of local management and support other areas of community economic development, including building coastal communities' capacity to adapt to the impacts of climate change.

The recent progress made by these communities in pioneering local coastal management, achieved in the absence of unified national structures to support these efforts, has been remarkable, and is unprecedented in the Indian Ocean. In recent years visiting fishers and conservationists from comoros, Mauritius, Kenya, Tanzania and Seychelles have travelled to visit southern Madagascar's LMMAs to learn about the steps involved in driving conservation at a local level, learning not from scientists or public officials, but from the fishing communities themselves. Moreover, the rapid replication of Madagascar's LMMAs illustrates the extent to which grassroots approaches offer low cost, adaptable and locally-acceptable solutions to coastal conservation challenges. Given the severe shortfalls and challenges currently facing Madagascar's national environmental governance capacity, Madagascar's LMMAs present an encouraging formula for the expansion of coastal conservation across the country at scale.

The promising growth in the geographical scope of marine conservation activity seen in Madagascar over the past decade has been matched by enlightened diversification of conservation activities. This has arisen in part through increasing recognition that restricting harvestable waters through area-based management may have a negative impact on local communities, both financially and socially, if not coupled with some form of compensatory economic intervention. A number of initiatives in Madagascar are currently pioneering new forms of community-based marine aquaculture, developed in parallel with coastal conservation activities. These include the Indian Ocean's first ranches of sea cucumbers Holothuria scabra, an extremely lucrative yet overexploited species, as well as algal culture of Kappaphycus alvarezii, a more widespread practice already prevalent in much of east Africa. In the former, juvenile holothurians are reared in hatcheries, then raised by communities in lagoonal enclosures (Robinson and Pascal 2009). Upon reaching commercial size, adults are harvested for international export through private sector partners, with profits being retained by community farmers. Such interventions help reduce pressure on overexploited wild stocks, while contributing to local economic development, helping families supplement traditional household income and reduce the number of people solely reliant on fishing.

Other novel diversification strategies have included the introduction of sexual and reproductive health services within coastal conservation initiatives, as part of integrated Population, Health and Environment (PHE) programmes. Such holistic approaches have emphasised the mutually beneficial synergies, supporting both public health and conservation objectives that can be created by incorporating family planning into more conventional biodiversity conservation activities (Harris et al. In press).

\section{CAPTURING THE UNREALISED ECONOMIC POTENTIAL OF MADAGASCAR'S COASTS}

LMMA networks present one low cost strategy for implementing decentralised coastal management at broad scale. However a significant challenge facing the management of a nationwide MPA network remains in the fact that almost all of the country's existing marine conservation efforts are entirely dependent on external finance, with negligible internal revenue generation capability. With the notable exception of a very small number of MPAs capable of collecting reliable tolls from tourism (notably the protected island of Nosy Tanikely in Diana region), Madagascar's MPAs are for the most part totally financially unsustainable, counting on parks service or donor finance to cover all management, monitoring, enforcement and infrastructural costs. External funding, generally provided by bilateral donors, NGOs and conservation foundations, is typically programmed around a preconceived and generally unrealistic 'end date', a fanciful point in the future after which MPAs will, it is hoped, have developed some form of sustainable financing strategy to ensure the long-term continuation of conservation efforts. Such a vision for financial sustainability rarely materialises, placing MPAs in a precarious position when their respective project end date comes around and funds dry up without any practicable entrepreneurial legacy.

As well as being reliant on donors, this 'standard' approach is also invariably managed and driven by outsiders; foreigners or Malagasy from outside the project region. As soon as the funding dries up, the outsiders also go. Thus when donor support ends, there is rarely any incentive for communities to maintain environmental management institutions in the long-term, nor adequate residual technical capacity among local managers. The result is a dismaying number of under-resourced MPAs whose development has either stopped in its tracks upon termination of funding, or whose operations have dwindled to the point of no longer having any local legitimacy or recognition beyond the paper dina or statute book.

Beyond its inherent instability, the donor-dependent project paradigm into which most MPAs are all too often locked is highly restricted, particularly given Madagascar's current economic outlook. Despite the critical role of insightful conservation financing institutions such as the Madagascar Foundation for Protected Areas and Biodiversity, there is simply not enough donor funding available to enable Madagascar to achieve its $30 \%$ target of marine protection. Overcoming this financing quandary will require creativity and innovation in developing new financing mechanisms for conservation efforts, demanding that conservation practitioners demonstrate that management makes economic sense to local communities. This will require turning conventional marine conservation finance models upside down to capture some of the additional economic benefits produced by MPAs. Many of these, such as the landing fees paid by tourists visiting Nosy Tanikely, can be lucrative and, if revenues are appropriately managed, may pave the way to financial sustainability. But ecotourism is far from being a panacea for Madagascar's coastal challenges - given the enormous scale of this continental island there are simply not enough tourists to bring sustainable revenue to manage $30 \%$ of the country's 5,500 km coastline. Beyond a few model sites blessed with adequate communications infrastructure, tourism services and reliable visitor numbers, sustainable 
marine conservation finance from tourism is an unrealistic expectation for Madagascar.

It is fisheries - the bedrock of most of the country's coastal economy - that present the obvious target for future sustainable finance initiatives. A bioeconomic analysis of the benefits of community-managed marine reserves in southern Madagascar has recently shown clear three-way fisheries, economic and social benefits derived from temporary octopus fishery closures, providing a compelling case to fisheries stakeholders to expand conservation efforts (Benbow et al. In press). As well as being instrumental in influencing communities to replicate similar management models further afield, these findings have tremendous potential to influence commercial fisheries companies to support fisheries management efforts, by demonstrating for the first time a business incentive for supporting conservation.

Exploring this example further, by following the supply chain of buyers and exporters attached to this particular fishery, it can be demonstrated that the benefits of the closures reach international markets, yet currently none of these beneficiaries contribute to management efforts to protect the fishery's sustainability, or help offset the opportunity cost shouldered by local fishermen when forgoing fishing in reserves. Given the demonstrable paybacks from management, clear opportunities exist to capture some of the concrete benefits accruing from marine conservation, to generate income for local managers on the ground, and to offset the opportunity cost currently borne by communities. Eco-certification of fisheries being managed by communities provides one way of increasing the financial incentive for communities and buyers alike to adopt sustainable management practices. The octopus fishery of southwest Madagascar is amongst the first traditional fisheries in Africa to be engaged in the Marine Stewardship Council (MSC) fishery certification process, in an attempt to gain access to more lucrative export markets that in turn impose stringent demands on ecological sustainability. Two other Malagasy fisheries are also now working with MSC, the world's largest certifier of environmentally-sustainable seafood, giving encouraging signs of growing industry awareness of the business benefits of sustainable fisheries management.

As long as a market exists, coastal communities - as sellers of ecosystem services - could be compensated for their effective resource management by existing ecosystem service buyers, giving fishing communities economic incentives, as well as the financial means, to conserve ecosystems that underpin their livelihoods and support biodiversity. Beyond fisheries, myriad other untapped potential revenue sources exist from the goods and services provided by coastal ecosystems, from storm protection and waste filtration to timber provision from mangroves. There is even potential for carbon markets to be adapted to incorporate coastal vegetation: a new research initiative in Menabe and Melaky is working to assess the feasibility of Madagascar linking the conservation of its mangrove and coastal wetland habitats to international carbon markets, as a means of bringing sustainable 'Blue Carbon' conservation finance through an (as yet hypothetical) marine REDD+ mechanism.

Whether from fisheries certification or carbon sequestration, all such approaches share the common theme of realising the economic value of marine natural capital as a sustainable long-term provider of ecosystem services, rather than as a finite resource to be felled or fished to depletion. Clearly, some such 'payment for ecosystem services' transactions are unlikely to evolve beyond theoretical frameworks or voluntary markets, but for the less fanciful ventures closer to short term market reality, the overriding advantage of business-based approaches to protecting marine biodiversity is their financial self-sufficiency and rapid scalability. Without drawing on any donor aid such conservation finance models can potentially allow for replication wherever there is a buyer. Further, revenues are constant as long as the underlying market remains favourable, overcoming the fateful project end date, the death knell for so many donor dependent marine protection initiatives. Similarly, the internal economic incentive strategy gives communities a motivation to participate in and maintain local management institutions in the long-term; put simply, if the local users' association is increasing fishing revenues, then why not maintain it?

Hence the toolkit of today's marine conservationist must now extend far beyond social and marine sciences to encompass social entrepreneurship, since it is our responsibility and overriding challenge to identify achievable income-generating opportunities to capture some of the diverse benefits accruing from sustainable marine management. The humbling task for the conservation entrepreneur will be to make the case that the short-term benefits of felling the last mangrove tree are eclipsed 100 -fold by the proven financial benefits of safeguarding the forest - until this is achieved, communities battling poverty, climate change and collapsing fisheries can have little incentive to change the status quo. And where the economic case cannot be made for the utilitarian value of marine biodiversity, it is down to Madagascar's growing marine conservation community to ensure that limited available donor funds are directed in a unified and coherent manner, based on coordinated dialogue between stakeholders.

\section{THE ROAD AHEAD}

Any move towards marine environmental sustainability must first reconcile the critical needs of Madagascar's coastal people. From family planning to improved education and livelihood diversification, marine conservation today is far more about poverty alleviation than it is about tallying taxa. Only by working for and alongside local communities can conservation efforts be truly sustainable and expandable. Moreover, given Madagascar's precarious political and economic outlook, implementation of socially-viable low cost management initiatives, as exemplified by Madagascar's growing LMMA network, represents the only realistic path to scaling conservation to develop resilient networks of marine protected areas. Robust local management is currently the only viable and truly replicable solution to achieving the $30 \%$ target, without which Madagascar cannot hope to contend with the pressures of population growth and climate change.

Successful local management efforts, however, can be completely undermined by outsider influences exploiting marine and coastal resources. On the water, itinerant 'artisanal' fishers, operating with motors and 'barrage' nets, sponsored sea cucumber dive teams equipped with scuba, industrial trawlers and illegal, unreported and unregulated fishing activities all present growing threats to coastal communities' ability to manage their coasts (Cripps 2009). Increasing competition between large industrial fleets and small scale fisheries will inevitably lead to increased marginalisation of small scale fish- 
ers (Pauly 2006). Onshore, communities face a similar slew of threats, often from developments of questionable legality. From loss of traditional coastal land for contentious hotel developments, to the devastating impacts of guano mining on small islands, locals can do little to control these outside forces, since activities authorised at a higher level will inevitably have the upper hand against local efforts. Current centralised decisionmaking mechanisms invariably hold sway over the voices of isolated coastal communities, no matter how united community groups may be. Clearly, therefore, the goal of achieving sustainable coastal management cannot be led by communities and the private sector alone. Policy must meet civil society half way, and truly give the means to local managers to control and defend their resources.

The creation in 2009 of a national cross-sector integrated coastal management committee (CN-GIZC) is an auspicious step towards improving decentralised decision-making and providing a coordinated national framework within which conservation activities can be embedded. The body incorporates a subcommittee whose monthly meetings focus exclusively on ecosystem management issues, and CN-GIZC's 5-year action plan specifically highlights as an over-riding objective the need to improve the economic condition of coastal communities (CN-GIZC 2010). Further supporting the growth in local coastal management, recent years have seen considerable strengthening of marine programmes within the country's three largest international conservation NGOs, and new organisations have developed focusing on marine protection, habitat restoration, aquaculture, education and research. This new civil society movement has become increasingly vocal around marine and coastal issues, and can play an influential role in advocacy and lobbying.

Looking ahead, as conservationists, the time has come to look beyond protecting marine biodiversity for the intrinsic value of coral reefs. We need to focus on demonstrating the value of healthy marine and coastal ecosystems as the building blocks of a sustainable future for communities that respect and guard their resources. If properly managed, Madagascar's vast $E E Z$, incorporating diverse coastal and offshore fisheries, could provide a secure long-term source of food security and foreign exchange. Our challenge is to prove this in real economic terms; showing what well-managed marine biodiversity is worth in terms of the untold and boundless services that healthy ecosystems provide. It is down to us to make this case, and we're working against the clock.

\section{ACKNOWLEDGEMENTS}

My sincere thanks go to Garth Cripps, Kame Westerman, Tantely Tianarisoa, Dimby Razafimpahanana, Raj Roy and three anonymous reviewers for input and invaluable comments on the manuscript.

\section{REFERENCES}

Ahamada, S., Bijoux, J., Cauvin, B., Hagan, A. B., Harris, A., Koonjul, M., Meunier, S. and Quod, J.-P. 2008. Status of the coral reefs of the SouthWest Indian Ocean Island States: Comoros, Madagascar, Mauritius, Reunion, Seychelles. In: Status of the Coral Reefs of the World. Wilkinson, C.R. (ed.), pp 73-79. Global Coral Reef Monitoring Network and Reef and Rainforest Research Centre, Townsville.

Andriamalala, G. and Gardner, C. J. 2010. L'utilisation du dina comme outil de gouvernance des ressources naturelles: leçons tirés de Velondriake, sud-ouest de Madagascar. Tropical Conservation Science 3, 4: 447-472.
Ateweberhan, M. and McClanahan, T. R. 2010. Relationship between historical sea-surface temperature variability and climate change-induced coral mortality in the Western Indian Ocean. Marine Pollution Bulletin 60: 964-970. (doi:10.1016/j.marpolbul.2010.03.033)

Balmford, A., Gravestock, P., Hockley, N., McClean, C. J. and Roberts, C. M. 2004. The worldwide costs of marine protected areas. Proceedings of the National Academy of Science, USA 101, 26: 9694-9697. (doi: 10.1073/pnas.0403239101)

Benbow, S., Harris A. and Humber F. In Press. Managing Madagascar's octopus fisheries. In: Proceedings of the Workshop on Octopus cyanea fisheries, 6-7 April 2011, Toliara. Blue Ventures Conservation, London.

Brooks, T. M., Mittermeier, R. A., da Fonseca, G. A. B., Gerlach, J., Hoffmann M., LamoreuX, J. F., Mittermeier, C. G., Pilgrim, J. D. and Rodrigues, A. S. L. 2006. Global biodiversity conservation priorities. Science 313: 58-61. (doi: 10.1126/science.1127609)

Burke, L, Reytar, K., Spalding, M. and Perry, A. (eds.) 2011. Reefs at Risk Revisited. World Resources Institute (WRI), Washington, D. C. http:// pdf.wri.org/reefs_at_risk_revisited.pdf >downloaded 25 April 2010.

Cinner, J. 2007. The role of taboos in conserving coastal resources in Madagascar. SPC Traditional Marine Resource Management and Knowledge Information Bulletin 22: 15-23.

Cinner, J., Daw, T. M. and McClanahan, T. R. 2009a. Socioeconomic factors that affect artisanal fishers' readiness to exit a declining fishery. Conservation Biology 23, 1: 124-130. (doi:10.1111/j.15231739.2008.01041.x)

Cinner, J., Fuentes, M., Randriamahazo, H. 2009b. Exploring social resilience in Madagascar's marine protected areas. Ecology and Society 14, 1: 41.

Cinner, J., Folke, C., Daw, T. and Hicks, C. 2011. Responding to change: using scenarios to understand how socioeconomic factors may influence amplifying or dampening exploitation feedbacks among Tanzanian fishers. Global Environmental Change 21, 1: 7-12. (doi:10.1016/j. gloenvcha.2010.09.001)

Cripps, G. 2009. Understanding migration amongst small-scale fishers in Madagascar. Blue Ventures Conservation, London. <http://blueventures.org/images/downloads/research/understanding-migration-\%20 jan11.pdf> downloaded 25 April 2011.

Cripps, G. 2010. Feasibility study on the protection and management of the Barren Isles ecosystem, Madagascar. Blue Ventures Conservation, London.

Comité National pour la Gestion Intégrée des Zones Côtières (CN-GIZC). 2010. Plan d'actions national pour la gestion intégrée des zones côtières: premier programme national de gestion intégrée des zones côtières, 2011-2015. CN-CIZC, Gouvernement de la République de Madagascar, Antananarivo.

Food and Agriculture Organisation of the United Nations (FAO). 2008. Fishery Country Profile, The Republic of Madagascar. Food and Agriculture Organisation of the United Nations. Rome.

Gell, F. R. and Roberts. C. M. 2002. The fishery effects of marine reserves and fishery closures. WWF-US, Washington, D. C.

Giri, C. P. and Muhlhausen, J. 2008. Mangrove forest distributions and dynamics in Madagascar (1975-2005). Sensors 8: 2104-2117. (doi: 10.1111/j.1365-2699.2007.01806.x)

Government of Madagascar (GoM) 2007. Madagascar Action Plan Commitment Seven: Cherish the Environment. Présidence de la République, Government of Madagascar, Antananarivo.

Harris, A. 2007. "To live with the Sea" Development of the Velondriake community-managed protected area network, southwest Madagascar. Madagascar Conservation \& Development 2: 43-49.

Harris, A., Manahira, G., Sheppard, A., Gough C., Sheppard C. 2010 Demise of Madagascar's once great barrier reef - change in coral reef condition over 40 years. Atoll Research Bulletin 574: 1-18.

Harris, A., Mohan, V., Flanagan, M. and Hill, R. In press. Integrating family planning service provision into community-based marine conservation. Oryx.

Institut National de la Statistique (INSTAT). 2007. Estimations de la population de Madagascar. Institut National de la Statistique de Madagascar, Antananarivo. 
Institut National de la Statistique (INSTAT) \& ICF Macro 2010. Enquête démographique et de santé de Madagascar 2008-2009. INSTAT et ICF Macro, Antananarivo.

IUCN. 2005. Benefits Beyond Boundaries. Proceedings of the Vth IUCN World Parks Congress. IUCN, Gland.

Johannes, R. E. 1978. Traditional marine conservation methods in Oceania and their demise. Annual. Review of Ecology and Systematics 9: 349-364. (doi:10.1146/annurev.es.09.110178.002025)

Laroche, J., and Ramananarivo, N. 1995. A preliminary survey of the artisana fishery on coral reefs of the Tulear Region (southwest Madagascar). Coral Reefs 14: 193-200. (doi:10.1007/BF00334341)

Laroche, J., Razanoelisoa, J., Fauroux, E., and Rabenevanana, M. W. 1997. The reef fisheries surrounding the south-west coastal cities of Madagascar. Fisheries Management and Ecology 4: 285-299. (doi:10.1046/j.1365-2400.1997.00051.x)

Le Manach, F., Gough, C., Harris, A., Humber, F., Harper, S. and Zeller, D. In press a. Unreported fishing, hungry people and political turmoil: the recipe for a food security crisis in Madagascar? Marine Policy.

Le Manach, F., Gough, C., Humber, F., Harper, S. and Zeller, D. In press b. Reconstruction of total marine fisheries catches for Madagascar (1950-2008). In: Fisheries catch reconstructions: Islands, Part II. S. Harper and D. Zeller (eds.), Fisheries Centre Reports 19. Fisheries Centre, University of British Columbia, Victoria. (doi: 10.1016/j.marpol.2011.05.007)

Myers, N. 1988. Threatened biotas: 'Hotspots' in tropical forests. The Environmentalist 8: 1-20.

Myers, N. 2003. Biodiversity hotspots revisited. Bioscience 53: 916-917. (doi:10.1641/0006-3568(2003)053[0916:BHR]2.0.CO;2)

Ostling, J. L., Butler, D. R. and Dixon, R. W. 2009. The biogeomorphology of mangroves and their role in natural hazards mitigation. Geography Compass 3, 5: 1607-1624. (doi:10.1111/j.1749-8198.2009.00265.x)
Pauly, D. 2006. Major trends in small-scale marine fisheries, with emphasis on developing countries, and some implications for the social sciences. MAST 4, 2: 7-22.

REBIOMA 2011. Réseau de la Biodiversité de Madagascar. <http://www. rebioma.net> accessed 25 April 2011.

Roberts, C. M., Mcclean, C. J., Veron, J. E. N., Hawkins, J. P., Allen, G. R., McAllister, D. E., Mittermeier, C. G., Schueler, F. W., Spalding, M., Wells F., Vynne, C. and Werner, T. B. 2002. Marine biodiversity hotspots and conservation priorities for tropical reefs. Science 295: 1280-1284. (doi:10.1126/science.1067728)

Robinson, G. and Pascal, B. 2009. From hatchery to community Madagascar's first village-based holothurian mariculture programme. SPC Beche-de-mer Information Bulletin 29: 38-43.

Vasseur, P. 1997. Ecosystèmes côtiers en danger dans la région de Tuléar: analyse des agressions humaines et problèmes de gestion. Milieux et sociétés dans le Sud-Ouest de Madagascar (collection lles et Archipels). CRET/Institut de Géographie-Université de Bordeaux III 23: 97-120.

Veron, J. E. N. and Turak, E. 2005. Zooxanthellate scleractinia of Madagascar. In: A rapid marine biodiversity assessment of the coral reefs of northwest Madagascar. S. A. McKenna and G. R. Allen (eds.), pp 23-25. Conservation International, Washington, D. C.

Veron, J. E. N., Devantier, L. M., Turak, E., Green, A. L., Kininmonth, S., Stafford-Smith, M. and Peterson, N. 2009. Delineating the Cora Triangle. Galaxea, Journal of Coral Reef Studies 11: 91-100.

World Bank 2011. Madagascar economic update: aid effectiveness during political instability - a look at social sectors. The World Bank, Washington, D. C.

World Resources Institute (WRI) 2003. EarthTrends: coastal and marine ecosystems, Madagascar. World Resources Institute, Washington D.C. 